\title{
Göğüs Cerrahisi Uygulanan Hastaların Konfor ve Anksiyete Düzeyini Etkileyen Faktörler
}

\section{Factors Affecting the Comfort and Anxiety Level of Patients Who Underwent Thoracic Surgery}

\author{
Besey ÖREN ${ }^{\mathrm{a}}$
}

ÖZ Giriş: Ameliyat sonrası dönemde cerrahi hastasında ortaya çıkabilen fiziksel ve psiko-sosyal sorunlar hastanın konforunu olumsuz etkileyerek iyileşme sürecini geciktirebilir. Çalışma göğüs cerrahisi olan hastaların konfor düzeyleri, konfor ile anksiyete ilişkisi ve etkili faktörleri belirlemek amacı ile tanımlayıcı olarak planlandı.

Gereç-Yöntem: Çalışmanın evrenini göğüs cerrahisi servisinde Aralık 2012-Aralık 2013 tarihleri arasında operasyon sonrası serviste yatan erişkin hastalardan; Türkçe iletişim kurulabilen, en az ilköğretim mezunu, psikolojik tedavi görmeyen, çalışmaya katılmaya istekli olup, onay veren 112 hasta oluşturdu. Veriler Bireysel Özellikler Formu, Erken Postoperatif Konfor Ölçeği, Genel Konfor Ölçeği, Durumluk-Sürekli Anksiyete Ölçeği kullanılarak yüz yüze görüşme yöntemi ile toplandı. Bulgular: Yaş ortalaması 51.71, olan hastaların \%47.3'ü ilköğretim mezunu, \%59,8'i sigara kullanmakta ve \%48.2'sine akciğer kanseri nedeniyle ameliyat uygulanmıştır. Grubun, \%67'sinin tek kişilik odada kaldığı, \%81.3'ünün kaldığı odadan memnun olduğu, \%81.3'ünün daha önce hastane deneyimi olduğu, \%69,6'sının daha önce ameliyat olduğu, \%94,6'sının hasta kabul sürecinden memnun olduğu saptandı. Hastaların erken postoperatif konfor düzeyi $4.96 \pm 0.56$, genel konfor düzeyi $2.89 \pm 0.32$ olarak belirlendi. Durumluk anksiyete düzeyi $49.05 \pm 4.50$, sürekli anksiyete düzeyi ise $46.37 \pm 4.57$ bulundu. Sonuç: Hastaların erken postoperatif konfor düzeyi ve genel konfor düzeyi ortalamanın üstünde tespit edilirken, durumluluk anksiyete düzeyi ve süreklilik anksiyete düzeyi orta düzeyde bulundu. Konfor ile anksiyete arasında negatif yönde bir ilişki olduğu, daha önce hastane deneyimi olması, cerrahi girişim süresi, geçirilmiş operasyon deneyiminin olması, kaldığı odadan memnun olup olmaması konfor ve anksiyeteyi etkileyen faktörler olarak tespit edildi.

Anahtar Kelimeler: Ameliyat sonrası bakım, göğüs cerrahisi, hemşirelik, konfor

ABSTRACT Introduction: Physical and psychosocial problems that may arise during a post-op period in a patient that underwent surgical intervention can negatively affect the comfort of the patient and, as a result, may delay the healing process. The study was planned as descriptive with the aim of determining the comfort levels of patients that had thoracic surgery, the relationship between comfort and anxiety and the factors influencing them. MaterialMethod: The study consisted of 112 patients who were able to communicate in Turkish, who were at least primary school graduates, who were not psychologically treated, who were willing to participate in the study and who approved the study, among adult patients who were in the thoracic surgery service between December 2012 and December 2013. Data were collected using the face-to-face interview method through Individual Characteristics Form, the Early Postoperative Comfort Scale, the General Comfort Scale, and the Circumstanced-Continuous Anxiety Scale. Results: $47.3 \%$ of the patients with an average age of 51.71 are primary school graduates. It was found that $59.8 \%$ of the patients were smokers, $48.2 \%$ were treated with lung cancer diagnosis, $67 \%$ were in single room, $81.3 \%$ were satisfied with the room, $81.3 \%$ had previous hospital experience, $69 \% 6$ had been operated before, and $94.6 \%$ were satisfied with the patient admission process. Early postoperative comfort level was $4.96 \pm 0.56$ and general comfort level was $2.89 \pm$ 0.32 . Circumstanced anxiety level was $49.05 \pm 4.50$, and continuous anxiety level was $46.37 \pm 4.57$. Conclusion: Early postoperative comfort level and general comfort level of patients were determined to be above the average. Circumstanced anxiety and continuous anxiety levels were moderate. There was a negative correlation between comfort and anxiety, and the factors affecting the anxiety were determined as having hospital experience, duration of surgical intervention, the experience of a previous operation, satisfaction with the room, and factors affecting comfort and anxiety.

Key Words: Postoperative care, thoracic surgery, nursing, comfort

\section{Giriş}

Cerrahi girişimler, yaşamı güvence altına alan uygulamalar olmakla beraber, bireyler için hem psikolojik hem de fizyolojik bir travmadir.
Ameliyat öncesi dönemde anestezi korkusu, anksiyete ve fiziksel bazı problemlere sebep olurken (1), ameliyat sonrası dönemde fiziksel ve

Geliş Tarihi/Received:25-03-2018. / Kabul Tarihi/Accepted:20-06-2018

a Dr.,Öğretim Üyesi, Sağlık Bilimleri Üniversitesi, Sağlık Bilimleri Fakültesi, Ebelik Bölümü, besey_oren@yahoo.com, ORCID:0000-0003-4182-7226 
psikososyal sorunlar, cerrahi girişimin süresi, girişim uygulanan organ (2), ağrı hissetme durumu (3), uykusuzluk (4,5), cerrahi girişime bağlı stres gibi birçok faktörden cerrahi hastası etkilenebilmektedir. Yapılan bir çalışmada cerrahi girişime bağlı yaşanan stresin hafif düzey ile panik düzeyi arasında değiştiği bildirilmektedir (6). Bütün cerrahi girişimlerde olduğu gibi komplikasyon insidansının \%15\%37.5 arasında değiştiği, göğüs cerrahisinin de birey üzerinde birçok olumsuz etkisi olduğu bildirilmektedir (7-10).

Fiziksel, psikospirituel, çevresel ve sosyokültürel boyutlarda ferahlama, rahatlama ve sorunların üstesinden gelme olarak tanımlanan konfor bütün cerrahi girişimlerde olduğu gibi göğüs cerrahisi sonrasında da hastaları olumsuz yönde etkiler $(2,11)$. Hemşirelik bakımının önemli bir bileșeni olan konfor (12), temel bir insan gereksinimidir ve kișiler bir sağlık sorunu ile karşılaştıklarında bu temel gereksinimlerinin sağlık profesyonelleri tarafindan karşılanacağını ümit ederler $(13,14)$. Nuraini ve ark (2017) hemşireler tarafindan tanımlanan ve hastanın konforunu etkileyen çevresel faktörler olarak; odanın kötü kokması, tanımadığı insanlarla birlikte aynı odayı paylaşmak, aynı odada kalan hastaların farklı alışkanlıklarının olması, tuvalet kullanma alışkanlığı, birisi konuşmayı tercih ederken öbürünün sessiz olup dinlenmek istemesi gibi farklılıkların etkili olduğunu belirtmişlerdir (15).

Sağlık çalışanları cerrahi girişim gibi travmatik olaydan hastanın fiziksel durumunun nasıl etkilendiğini çoğu zaman önemserken, psikolojisi ve konforunun nasıl etkilendiğini göz ardı edilebilmektedirler $(15,16)$. Hemşireler genellikle hastanın konforunu sağlamak için ağrıya odaklanmaktadır (16). Hastayı koruma kollama ve rahatlatma felsefesi üzerine temellenen hemşireliğin önemli ilgi alanlarından birisi, hasta konforunun sağlanması ve sürdürülmesidir (2).

\section{Gereç ve Yöntem}

\section{Araştırmanın Amacı}

Çalışma göğüs cerrahisi olan hastaların konfor düzeyleri ile anksiyete ilişkisini ve etkili faktörleri belirlemek amacı ile tanımlayıcı olarak planlandi.

\section{Araştırmanın evren ve örneklemi}

Araştırmanın evrenini İstanbul' daki bir üniversite hastanesinin gögüs cerrahisi servisinde Aralık 2012-Aralık 2013 tarihleri arasinda yatan yaklaşık 458 hasta, örneklemini ise, bu hastalar arasından seçilen; 18-72 yaşları arasında, Türkçe iletişim kurulabilen, en az ilköğretim mezunu, cerrahi uygulama sonrası konforu olumsuz yönde etkileyeceği düşünülen ilave hastalık tanısı konulmamış, psikolojik tedavi görmeyen, çalışmaya katılmaya istekli olup, onay veren 112 hasta oluşturdu.

\section{Veri Toplama Araçları}

Veriler Hasta Bilgi Formu, Erken Postoperatif Konfor Ölçeği (EPKÖ), Genel Konfor Ölçeği (GKÖ), Durumluluk-Süreklilik Anksiyete Ölçeği (DSAÖ) kullanılarak yüz yüze görüşme yöntemi ile toplandi.

\section{Hasta Bilgi Formu}

Hastanın yaşı, cinsiyeti, yaşadığı yer, medeni durumu, aylık geliri gibi demografik özellikleri ile hastalık tanısı, cerrahi girişim süresi, daha önce operasyon geçirip geçirmediği, hastane deneyiminin olup olmadığı, hasta kabul sürecinden memnuniyeti, oda tipi, odasindan memnun olup olamadiğ sunulan hizmetlerden memnuniyeti ile ilgili 2 açık uçlu ve 17 kapalı uçlu olmak üzere 19 sorudan oluşan bir formdur.

\section{Erken Postoperatif Konfor Ölçeği (EPKÖ)}

Erken postoperatif konfor ölçeği, konforun kuramsal bileşenlerini oluşturan üç düzey ve dört boyutun yer aldığı taksonomik yap1 rehber alınarak oluşturulmuştur. Bireyin cerrahi girişim önce ve sonrası hakkında genel düşünce sürecini yansitan kendini kavrama ve hislerini sorgulamaktadır. Likert tipi 1-6 arasında (katılmıorum- kesinlikle katılıyorum) derecelendirilen ölçek 12 pozitif $(1,5,6,11,14,16,18,19$, 20, 21, 23, 24), 12 negatif $(2,3,4,7,8,9,10,12$, $13,15,17,22$ ) olmak üzere toplam 24 ifadeden oluşmaktadır. Değerlendirmede elde edilen negatif puanlar ters kodlanarak pozitif maddelerle toplanır. Ölçekten alınabilecek en yüksek toplam puan 144, en düşük toplam puan ise 24 dür. Elde edilen toplam puan ölçek maddelerinin sayısına bölünerek ortalama değer saptanır ve sonuç 1-6 
arasında değerlendirilir. Düşük puan konforun kötü, yüksek puan ise konforun iyi olduğunu göstermektedir (2).

Ölçeğin Türk toplumunda kullanımını sınamak amacıyla güvenilirlik ve geçerlik çalışması 2007 yılında Üstündağ ve Eti tarafından yapılmış olup Cronbach's alfa katsayısı 0.83 olarak bulunmuştur (17). Mevcut çalışmada Cronbach's alfa katsayısı 0,73 olarak bulunmuştur.

\section{Genel Konfor Ölçeği}

Genel Konfor Ölçeği Kolcaba tarafindan 1992 yılında geliştirilmiştir (18). Konforun kuramsal bileşenlerini oluşturan üç düzey ve dört boyutun yer aldığ1 taksonomik yap1 rehber alınarak oluşturulmuş olup gereksinimlerin belirlenmesi, konfor sağlayan hemşirelik girişimleri ile konfor durumunu değerlendirmek için kullanılmaktadır. Ölçek dörtlü likert tipte olup toplam 48 madde içermektedir (19).

Pozitif ve negatif maddelerden oluşan ölçeğin yanıt düzenleri karışık halde verilmiştir. Ölçeğin değerlendirilmesinde, elde edilen negatif puanlar ters kodlanarak pozitif maddelerle toplanır. Ölçekten alınabilecek en düşük toplam puan 48, en yüksek toplam puan 192'dir. Elde edilen toplam puan ölçek maddelerinin sayısına bölünerek ortalama değer saptanır ve sonuç 1-4 arasında değerlendirilir. Düşük puan konforun kötü, yüksek puan konforun iyi olduğunu göstermektedir (19).

Ölçeğin Türk toplumu için uygunluğu Kuğuoğlu ve Karabacak tarafından 2004 yılında yapılmıştır. Kuğuoğlu ve Karabacak ölçeğin Cronbach's alfa katsayısını 0.85 olarak bulmuş ve ölçeğin güvenirliğinin yüksek olduğunu saptamışlardır. Mevcut çalışmada ölçeğin yeniden değerlendirilen iç tutarlılık incelemesinde Cronbach's alfa katsayısı 0.83 olarak bulundu.

Kolcaba konfor ile ilgili çalışmalarında elde ettiği sonuçlar doğrultusunda; konforun süreklilik özelliğinden çok durumluk özelliği gösterdiğini, konforun bütüncül yapısı nedeni ile ölçeğin kuramda açıklanan üç düzey ve dört boyutu içeren alt bölümler şeklinde değil bir bütün olarak değerlendirilmesinin daha doğru sonuçlar verdiğini saptamıştır (11).

\section{Durumluk - Sürekli Anksiyete Ölçeği}

Durumluluk ve süreklilik anksiyete düzeylerini saptamak amaciyla Spielberger ve arkadaşları tarafından (1970) geliştirilen (20), Öner ve Le Compte tarafından Türk toplumunda geçerlilik ve güvenirlilik çalışmaları yapılan ölçek (21), iki faktörlü anksiyete kavramına dayanarak geliştirilen toplam 40 maddeden oluşan iki ayrı bölümü içerir. Ölçekteki maddelerden ilk 20'si duruma bağlı anksiyete düzeyini, 21'den 40'a kadar olan maddeler ise bireyin sürekli anksiyete düzeyini ölçmektedir. Ölçekte maddeler doğrudan ve tersine dönmüş ifadeler olarak ayrılmış olup; doğrudan ifadeler olumsuz duygular1, tersine dönmüş ifadeler ise olumlu duyguları dile getirmektedir (21).

Durumluk Anksiyete Ölçeği, bireyin belirli bir anda ve belirli koșullarda kendini nasıl hissettiğini belirlemektedir. Ölçeğin yanıtlanmasında; maddelerin ifade ettiği duyuş, düşünce ya da davranışların şiddetinin derecesine göre "hiç" (1), "biraz" (2), "çok" (3), "tamamıyla" (4) seçeneklerinden birinin işaretlenmesi istenir. $\mathrm{Bu}$ bölümde; 1., 2., 5., 8., 10., 11., 15., 16., 19. ve 20. ifadeler ters kodlanarak değerlendirilir. Ölçeğin değerlendiril-mesinde doğrudan ifadelerin toplam puanından tersine dönmüş ifadelerin toplam puanı çıkartılır, elde edilen değere durumluk anksiyete ölçeğinin değişmez değeri olan 50 sayıs1 eklenerek durumluk anksiyete puanı elde edilir (21).

Sürekli Anksiyete Ölçeği (ST, bireyin genellikle kendini nasıl hissettiğini belirlemek için kullanılmaktadır. Ölçeğinin yanıtlanmasında maddelerin ifade ettiği duyuş, düşünce ya da davranışların sıklık derecesine göre "hemen hiçbir zaman" (1), "bazen" (2), “çok zaman” (3) ve "hemen her zaman" (4) seçeneklerden birini işaretlemesi istenir. Bu bölümde 21., 26., 27., 30., 33., 36., 39. maddeler olmak üzere yedi ifade ters kodlanır. $\mathrm{Bu}$ bölümün değerlendirilmesinde doğrudan ifadelerin toplam puanından, tersine dönmüş ifadelerin toplam puanı çıkartılır, sürekli anksiyete ölçeğinin değişmez değeri olan 35 sayıs1 eklenerek bireyin sürekli anksiyete puanı elde edilir (21). Ölçekten elde edilen, 20-39 puan "hafif", 40-59 puan "orta derecede" 60-79 puan 
"ağır anksiyete", 80 puan ise "panik" olarak değerlen-dirilmektedir (20). Mevcut çalışmada ölçeğin yeniden değerlendirilen iç tutarlılık incelemesin-de durumluk anksiyete Cronbach's alfa katsayısı 0.88 , sürekli anksiyete Cronbach's alfa katsayısı 0.81 , toplam Cronbach's alfa katsayısı 0.90'dır.

\section{Verilerin Toplanması}

Veriler araştırmacılar tarafindan veri toplama araçları kullanılarak toplandı. EPKÖ operasyondan sonraki ilk gün, GKÖ ve STAI (Sürekli-Durumluluk Anksiyete Ölçeği) cerrahi girişim sonrası 2-7. günler arası uygulandı.

\section{Verilerin Değerlendirilmesi}

Araştırma sonucunda elde edilen verilerin istatistik analizleri SPSS paket programı ile bilgisayarda yapıldı. Elde edilen verilerin değerlendirilmesinde; Tanımlayıcı istatistiksel yöntemler; oran, ortalama, standart sapma, gruplar arası kıyaslamalarda değişkenin tipi ve gruplara düşen örnek sayılarına göre Mannwhitney U testi, Kruskall-Wallis, grup sayıs1 ikiden fazla olan kıyaslamalarda sperman korelasyon analizi ile değerlendirildi. İstatistiksel anlamlilık $\mathrm{p}<0.05$ olarak kabul edildi.

\section{Araştırmanın Etik Yönü}

Çalışmaya başlamadan önce hastalara çalışma ile ilgili bilgi verilerek sözlü onamları alındı. Ayrıca çalışmanın yürütüleceği ilgili birimden ve bir üniversite hastanesinin etik kurulundan izin alınd.

\section{Bulgular}

Çalışma kapsamına alınan hastaların yaş ortalamalar1 51,71, \%63.4'ü erkek, \%47,3'ü ilköğretim mezunuydu. \%56.3'ünün aylık gelirinin yeterli olmadiğı, \%82,1'nin çocuğunun olduğu, \%59,8'inin sigara içtiği belirlendi. \%48,2'sinin tanıs1 akciğer kanseriydi. Hastaların \%67'si tek kişilik odada kaldığını, \%81,3’ü kaldığı odadan memnun olduğunu, \%81,3'ü daha önce hastane deneyimi olduğunu, \%69,6's1 daha önce ameliyat olduğunu, \%94,6's1 hasta kabul sürecinden memnun olduğunu ifade etti (Tablo 1).

Kaldığı odadan memnun olan olmayan hastalar karşılaştırıldığında istatistiksel olarak anlamlı fark görüldü. Kaldığı odadan memnun olan hastaların süreklilik anksiyete düzeyi yüksek $(\mathrm{p}<0.05)$ bulundu. (Tablo 1). Hastane deneyimi olan ve olmayanların GKÖ puanı karşılaştırıldiğında istatistiksel anlamlı fark saptandı $(p=0,040)$ Hastane deneyimi olmayanların GKÖ puanı daha yüksek bulundu (Tablo 1). Geçirmiş operasyon deneyimi olan veya olmayan gruplar karşılaştırıldığında istatistiksel anlamlı fark saptand $1 \quad(p=0,040)$. Daha önce operasyon geçirmiş olanların EPKO puanının daha yüksek olduğu görüldü. Daha önce operasyon deneyiminin olmasinın erken post-op konforu olumlu etkilediği görüldü (Tablo 1).

Erken postoperatif konfor düzeyi $4,96 \pm 0,56$, genel konfor düzeyi $2.89 \pm 0.32$ bulundu. Hastalarin erken postoperatif konfor düzeyi ve genel konfor düzeyi ortalamanın üstünde tespit edildi. Durumluk anksiyete düzeyi $49,05 \pm 4.50$, sürekli anksiyete düzeyi ise 46,37$\pm 4,57$ olarak bulundu. Durumluluk anksiyete düzeyi ve sürekli anksiyete düzeyi orta derecede bulundu (Tablo 2).

Hastaların genel konfor düzeyi; cerrahi girişimin süresi, durumluluk anksiyetesi ile negatif yönde, erken postoperatif konfor ile pozitif yönde ilişkili bulundu $(\mathrm{p}<0.05)$. Cerrahi girişim süresi ve durumluluk anksiyetesi arttıkça genel konfor düzeyi azalmaktadır. Erken postoperatif konfor ile durumluluk anksiyetesi arasında da negatif yönde ilişki olduğu görüldü $(p<0.005)$. Durumluluk anksiyetesi arttıkça erken post operatif konfor düzeyinin azaldı $\breve{g}_{1}$ tespit edildi. Genel konfor düzeyi ile erken postoperatif konfor düzeyi pozitif yönde ilişkili bulundu. Erken postoperatif dönemde konfor düzeyi artarken, genel konfor düzeylerinin de arttığ 1 saptand1 (Tablo 3). 
Tablo 1. Olguların sosyodemografik özellikleri ve konfor, anksiyete durumlarının incelenmesi

\begin{tabular}{|c|c|c|c|c|c|c|c|c|c|c|}
\hline \multicolumn{5}{|c|}{ Yaş (Mean \pm SS/Median (Dağılım aralığ1) } & \multicolumn{6}{|c|}{$51,71 \pm 15,73 / 55(6-79)$} \\
\hline \multicolumn{5}{|c|}{ Operasyon Süresi (Mean \pm Sd/Median (Dağılım aralığı) saat } & \multicolumn{6}{|c|}{$2,36 \pm 1,03 / 2,08(0,5-6)$} \\
\hline & $\mathrm{N}$ & $\%$ & EPKO & $\begin{array}{l}\text { İstatistik } \\
\text { analiz }\end{array}$ & GKO & İstatistik & $\begin{array}{l}\text { Durumluluk } \\
\text { Anksiyete }\end{array}$ & $\begin{array}{l}\text { İstatistik } \\
\text { analiz }\end{array}$ & $\begin{array}{l}\text { Süreklilik } \\
\text { Anksiyete }\end{array}$ & $\begin{array}{l}\text { İstatistik } \\
\text { analiz }\end{array}$ \\
\hline $\begin{array}{l}\text { Cinsiyet } \\
\text { Kadın } \\
\text { Erkek }\end{array}$ & $\begin{array}{l}41 \\
71\end{array}$ & $\begin{array}{l}36,6 \\
63,4\end{array}$ & $\begin{array}{l}5,02 \pm 057 \\
4,92 \pm 0,55\end{array}$ & $\begin{array}{l}\mathrm{U}=1296,0 \\
\mathrm{p}=0,33\end{array}$ & $\begin{array}{l}2,91 \pm 0,34 \\
2,89 \pm 0,34\end{array}$ & $\begin{array}{l}\mathrm{U}=1425,5 \\
\mathrm{p}=0,85\end{array}$ & $\begin{array}{l}48,29 \pm 4,06 \\
49,46 \pm 4,71\end{array}$ & $\begin{array}{l}U=1257,0 \\
p=0,22\end{array}$ & $\begin{array}{l}47,04 \pm 3,70 \\
45,98 \pm 4,99\end{array}$ & $\begin{array}{l}\mathrm{U}=1255,5 \\
\mathrm{p}=0,22\end{array}$ \\
\hline $\begin{array}{l}\text { Medeni Durumu } \\
\text { Evli } \\
\text { Bekar }\end{array}$ & $\begin{array}{l}93 \\
19\end{array}$ & $\begin{array}{l}83,0 \\
17,0\end{array}$ & $\begin{array}{l}4,94 \pm, 56 \\
5,07 \pm, 59\end{array}$ & $\begin{array}{l}U=759,0 \\
p=0,33\end{array}$ & $\begin{array}{l}2,89 \pm, 31 \\
2,96 \pm, 39\end{array}$ & $\begin{array}{l}\mathrm{U}=742,0 \\
\mathrm{p}=0,27\end{array}$ & $\begin{array}{l}49,14 \pm 4,56 \\
48,53 \pm 4,27\end{array}$ & $\begin{array}{l}\mathrm{U}=820,0 \\
\mathrm{p}=0,62\end{array}$ & $\begin{array}{l}46,25 \pm 4,81 \\
47,00 \pm 3,23 \\
\end{array}$ & $\begin{array}{l}\mathrm{U}=773,5 \\
\mathrm{p}=0,39\end{array}$ \\
\hline $\begin{array}{l}\text { Eğitim Durumu } \\
\text { İlköğretim } \\
\text { Orta Öğretim } \\
\text { Yüksek Öğretim } \\
\end{array}$ & $\begin{array}{l}53 \\
29 \\
30 \\
\end{array}$ & $\begin{array}{l}47,3 \\
25,9 \\
26,8 \\
\end{array}$ & $\begin{array}{l}4,88 \pm 0,51 \\
5,06 \pm 0,55 \\
5,01 \pm 0,65 \\
\end{array}$ & $\begin{array}{l}\mathrm{KW}=3,56 \\
\mathrm{p}=0,16\end{array}$ & $\begin{array}{l}2,90 \pm 0,29 \\
2,92 \pm 0,42 \\
2,89 \pm 0,29 \\
\end{array}$ & $\begin{array}{l}\mathrm{KW}=0,26 \\
\mathrm{p}=0,87\end{array}$ & $\begin{array}{l}49,25 \pm, 4,34 \\
48,52 \pm, 3,78 \\
49,17 \pm, 5,45 \\
\end{array}$ & $\begin{array}{l}\mathrm{KW}=0,44 \\
\mathrm{p}=0,80\end{array}$ & $\begin{array}{l}46,26 \pm, 4,48 \\
46,59 \pm, 4,84 \\
46,37 \pm, 4,65 \\
\end{array}$ & $\begin{array}{l}\mathrm{KW}=0,22 \\
\mathrm{p}=0,89\end{array}$ \\
\hline $\begin{array}{l}\text { Sigara içme } \\
\text { Evet } \\
\text { Hayır }\end{array}$ & $\begin{array}{l}67 \\
45 \\
\end{array}$ & $\begin{array}{l}59,8 \\
40,2 \\
\end{array}$ & $\begin{array}{l}4,97 \pm, 53 \\
4,95 \pm, 61 \\
\end{array}$ & $\begin{array}{l}\mathrm{U}=1500,0 \\
\mathrm{p}=0,96\end{array}$ & $\begin{array}{l}2,90 \pm 0,30 \\
2,90 \pm 0,36 \\
\end{array}$ & $\begin{array}{l}\mathrm{U}=1459,5 \\
\mathrm{p}=0,776\end{array}$ & $\begin{array}{l}8,94 \pm 4,42 \\
49,18 \pm 4,67\end{array}$ & $\begin{array}{l}\mathrm{U}=1473,0 \\
\mathrm{p}=0,837\end{array}$ & $\begin{array}{l}46,55 \pm, 4,95 \\
46,11 \pm, 4,01 \\
\end{array}$ & $\begin{array}{l}\mathrm{U}=1448,5 \\
\mathrm{p}=0,725\end{array}$ \\
\hline $\begin{array}{l}\text { Tibbi tanı } \\
\text { Akciğer Ca } \\
\text { Akciğer Metastatik Ca } \\
\text { Göğ̈̈s Duvarı Ca } \\
\text { Plevral Effüzyon } \\
\text { Akciğer Kistik Hast. } \\
\text { Pnomotoraks } \\
\text { Diğer }\end{array}$ & $\begin{array}{l}54 \\
17 \\
9 \\
6 \\
6 \\
5 \\
15 \\
\end{array}$ & $\begin{array}{l}48,2 \\
15,2 \\
8,0 \\
5,4 \\
5,4 \\
4,5 \\
13,4\end{array}$ & $\begin{array}{l}4,96 \pm 0,54 \\
5,08 \pm 0,70 \\
4,97 \pm 0,46 \\
4,80 \pm 0,68 \\
4,66 \pm 0,69 \\
4,77 \pm 0,33 \\
5,08 \pm 0,48\end{array}$ & $\begin{array}{l}\mathrm{KW}=5,23 \\
\mathrm{p}=0,515\end{array}$ & $\begin{array}{l}2,87 \pm 0,31 \\
2,86 \pm 0,28 \\
3,11 \pm 0,46 \\
2,91 \pm 0,27 \\
2,96 \pm 0,33 \\
2,75 \pm 0,34 \\
2,93 \pm 0,36\end{array}$ & $\begin{array}{l}\mathrm{KW}=3,44 \\
\mathrm{p}=0,752\end{array}$ & $\begin{array}{l}48,52 \pm 3,54 \\
49,71 \pm 5,24 \\
51,67 \pm 3,74 \\
47,67 \pm 4,76 \\
48,83 \pm 7,31 \\
53,00 \pm 7,31 \\
47,87 \pm 4,19\end{array}$ & $\begin{array}{l}\mathrm{KW}=7,75 \\
\mathrm{p}=0,257\end{array}$ & $\begin{array}{l}6,22 \pm 5,11 \\
45,94 \pm 3,78 \\
45,33 \pm 3,24 \\
45,83 \pm 5,78 \\
51,17 \pm 3,54 \\
46,00 \pm 3,24 \\
46,47 \pm 3,85\end{array}$ & $\begin{array}{l}\mathrm{KW}=8,58 \\
\mathrm{p}=0,199\end{array}$ \\
\hline $\begin{array}{ll}\text { Odadan memnunniy } \\
\text { durumu } \\
\text { Evet } \\
\text { Hayır }\end{array}$ & $\begin{array}{l}91 \\
21\end{array}$ & $\begin{array}{l}81,3 \\
18,7\end{array}$ & $\begin{array}{l}4,96 \pm, 58 \\
4,98 \pm, 46\end{array}$ & $\begin{array}{l}\mathrm{U}=944,5 \\
\mathrm{p}=0,935\end{array}$ & $\begin{array}{l}2,92 \pm, 32 \\
2,82 \pm, 33\end{array}$ & $\begin{array}{l}\mathrm{U}=750,0 \\
\mathrm{p}=0,125\end{array}$ & $\begin{array}{l}48,79 \pm 4,46 \\
50,10 \pm 4,65\end{array}$ & $\begin{array}{l}\mathrm{U}=795,0 \\
\mathrm{p}=0,230\end{array}$ & $\begin{array}{l}46,81 \pm 4,65 \\
44,48 \pm 3,78\end{array}$ & $\begin{array}{l}U=685,0 \\
p=0,043\end{array}$ \\
\hline $\begin{array}{l}\text { Hastane deneyimi } \\
\text { Evet } \\
\text { Hayır }\end{array}$ & $\begin{array}{l}91 \\
21\end{array}$ & $\begin{array}{l}81,3 \\
18,8 \\
\end{array}$ & $\begin{array}{l}4,97 \pm, 59 \\
4,91 \pm, 42 \\
\end{array}$ & $\begin{array}{l}\mathrm{U}=846,0 \\
\mathrm{p}=0,414\end{array}$ & $\begin{array}{l}2,87 \pm, 33 \\
3,03 \pm, 28 \\
\end{array}$ & $\begin{array}{l}U=679,5 \\
p=0,04\end{array}$ & $\begin{array}{l}49,30 \pm 4,46 \\
47,90 \pm 4,62\end{array}$ & $\begin{array}{l}\mathrm{U}=772,5 \\
\mathrm{p}=0,171\end{array}$ & $\begin{array}{l}46,15 \pm 4,67 \\
47,33 \pm 4,14 \\
\end{array}$ & $\begin{array}{l}\mathrm{U}=750,0 \\
\mathrm{p}=0,124\end{array}$ \\
\hline $\begin{array}{ll}\text { Geçirmiş } & \text { operasy } \\
\text { deneyi mi } & \\
\text { Evet } & \\
\text { Hayır } & \\
\end{array}$ & $\begin{array}{l}78 \\
34\end{array}$ & $\begin{array}{l}69,6 \\
30,4\end{array}$ & $\begin{array}{l}5,02 \pm, 59 \\
4,83 \pm, 47\end{array}$ & $\begin{array}{l}U=1006,5 \\
p=0,04\end{array}$ & $\begin{array}{l}2,89 \pm, 33 \\
2,92 \pm, 32\end{array}$ & $\begin{array}{l}U=1236,5 \\
p=0,57\end{array}$ & $\begin{array}{l}49,23 \pm 4,18 \\
48,59 \pm 5,20\end{array}$ & $\begin{array}{l}U=1164,0 \\
p=0,30\end{array}$ & $\begin{array}{l}46,49 \pm 4,74 \\
46,12 \pm 4,24\end{array}$ & $\begin{array}{l}\mathrm{U}=1295,0 \\
\mathrm{p}=0,84\end{array}$ \\
\hline $\begin{array}{l}\text { Kabul sürecinden } \\
\text { memnunniyet }\end{array}$ & & & & & & & & & & \\
\hline $\begin{array}{l}\text { Evet } \\
\text { Hayır }\end{array}$ & $\begin{array}{l}106 \\
6\end{array}$ & $\begin{array}{l}94,6 \\
5,4\end{array}$ & $\begin{array}{l}4,95 \pm, 56 \\
5,21 \pm, 53\end{array}$ & $\begin{array}{l}\mathrm{U}=234,5 \\
\mathrm{p}=0,28\end{array}$ & $\begin{array}{l}2,90 \pm, 33 \\
2,92 \pm, 12\end{array}$ & $\begin{array}{l}\mathrm{U}=282,0 \\
\mathrm{p}=0,64\end{array}$ & $\begin{array}{l}49,01 \pm 4,52 \\
49,50 \pm 4,59\end{array}$ & $\begin{array}{l}\mathrm{U}=294,5 \\
\mathrm{p}=0,76\end{array}$ & $\begin{array}{l}46,43 \pm 4,70 \\
45,33 \pm, 82\end{array}$ & $\begin{array}{l}\mathrm{U}=278,5 \\
\mathrm{p}=0,60\end{array}$ \\
\hline
\end{tabular}


Tablo 2. Ölçeklerin puan dağglımı

\begin{tabular}{llll}
\hline & Mean+ SD & Median & Dağılım aralı̆̆ \\
\hline EPKO TOP & $4,96 \pm 0,56$ & 5,02 & $3,33-5,92$ \\
\hline GKO & $2,89 \pm 0,32$ & 2,87 & $1,65-3,85$ \\
\hline Durumluk & $49,03 \pm 4,50$ & 49,00 & $41,00-64,00$ \\
\hline Süreklilik & $46,37 \pm 4,57$ & 46,00 & $35,00-60,00$
\end{tabular}

Tablo 3. Cerrahi girişim süresi, anksiyete ve konfor ilişkisi

\begin{tabular}{|c|c|c|c|c|c|}
\hline & & $\begin{array}{l}\text { Cerrahi Girişim } \\
\text { Süresi }\end{array}$ & Durumluk & Süreklilik & EPKO \\
\hline \multirow[t]{2}{*}{ GKO } & $\mathrm{r}$ & $-0,199 *$ & $-0,390 * *$ & 0,068 & $0,291 * *$ \\
\hline & $\mathrm{p}$ & 0,036 & 0,000 & 0,479 & 0,002 \\
\hline \multirow[t]{2}{*}{ EPKO } & $\mathrm{r}$ & & $-0,196^{*}$ & & \\
\hline & $\mathrm{p}$ & & 0,038 & & \\
\hline
\end{tabular}

\section{Tartışma}

Cerrahi girişimler, hastanın yaşamında beklenmedik olumsuz bir yaşam deneyimidir. Alışılmış yaşam ortamı ve tarzından farklılık gösteren bu dönem, stresli, az ya da çok komplikasyonların gelişebileceği, işlevlerinde bazı değişikliklerin olabileceği, ruhsal ve bedensel bütünlüklerini tehlikeye sokabilecek olayların yaşanmasını ve konforlarının bozulmasını etkileyen pek çok faktörün olduğu dönemlerdir. Bu çalışmada göğüs cerrahisi uygulanan hastaların konfor düzeyi, konfor ile anksiyete ilişkisi ve etkileyen faktörler incelendi.

Çoğunluğu akciğer kanseri nedeniyle ameliyat olan hastaların erken postoperatif konfor düzeyi ve genel konfor düzeyi ortalamanın üstünde, durumluluk anksiyete düzeyi ve sürekli anksiyete düzeyi orta derecede tespit edildi. Üstündağ'ın (2009) göğüs kalp damar hastaları ile yaptığı çalışmada da hastaların genel konfor düzeyi ve erken postoperatif konfor düzeyi yüksek; durumluluk ve süreklilik anksiyeteleri orta düzeyde bulunmuştur (2). Cerrahi hastalarında yapılan bir çalışmada da benzer şekilde hastaların postoperatif dönemde orta düzeyde anksiyete yaşadıkları bildirilmiştir (22).

Kronik hastalık nedeniyle hastaneye yatan hastaların hemşirelik hizmetlerinden memnuniyet ve konforlarının değerlendirildiği çalışmada hastaların genel olarak memnun oldukları ve özellikle diyabet hastalarının diğer kronik hastalığ olan hastalara göre konfor düzeylerinin yüksek olduğu bildirilmiştir (23). Başka bir çalışmada ise, konfor ve umut arasında doğrudan ve anlamlı bir ilişki olduğu ve ümit etme düzeyi yüksek olan hastaların konforlarının da daha iyi olduğu, eğitim seviyesi, cinsiyet ve medeni durum gibi demog- 
rafik özelliklerin de konforu ve ümidi etkilediği bildirilmiştir (14).

Konfor ve anksiyete ilişkisi incelendiğinde konfor ile anksiyete arasında negatif yönde bir ilişki olduğu, konfor düzeyi yüksek olan hastaların anksiyetelerinin düşük olduğu belirlendi. Özellikle durumluluk anksiyetesi arttıça erken post operatif konfor düzeyi azalmaktadır. Üstündağ'ın çalışmasında da benzer sonuçlar elde edilmiştir (2). Konforun ferahlama, huzura kavuşma gibi anlamları olduğu, buna karşın anksiyetenin belirsizliklerin ortaya çıkardığı yorgunluk, sinirlilik, huzursuzluk, hoş olmayan bir gerilim duygusu olduğu düşünüldügünde bu negatif yönlü ilişki doğaldır $(2,11,12)$.

Çalışmamızda; daha önce hastane deneyimi olması, cerrahi girişim süresi, geçirilmiş operasyon deneyiminin olması, yattı̆̆1 odadan memnun olup olmanın konfor ve ansiyeteyi etkilediği bulunmuștur. Daha önce hastane deneyimi olanların ve operasyon süresi uzun olanların genel konfor düzeyi düşük iken; geçirilmiş operasyon deneyimi olan hastaların erken postoperatif konforları yüksek bulunmuştur. Odasından memnun olan hastaların ise sürekli anksiyeteleri yüksek bulunmuştur.

Daha önce hastane deneyimi olması hastanın neyle karşılaşabileceğini bilmesi, hastane ortamının ve cerrahi girişimin yaratacağı ağrı gibi olumsuzlukların hatırlamasına ve böylece konforu olumsuz etkilenmesine neden olabilir. Cerrahi girişim süresi uzadıkça yaşanabilecek olumsuzlukların da artacağ etkileyebilir. Araştırmalar, hayal gücünü olumlu bir şekilde odaklamanın, herkesin fiziksel ve zihinsel sağlık durumunu yeniden tesis etmesine olanak tanıdığını, kolaylık, cesaretlendirme ve duygu durum düzenlemesi ile sonuçlanabileceğini göstermektedir. Ancak olumsuz deneyimlerin hatırlanması da aynı zamanda olumsuz duygular hissedilmesine neden olabilir (24).

Olguların geçirilmiş operasyon deneyiminin erken postoperatif konforu olumlu etkilediği görülmüştür. $\mathrm{Bu}$ sonuçta olguların geçirilmiş tecrübeden dolayı yaşayacağı süreci önceden bilmesi ve nasıl yöneteceğini planlamış olmasının, ağrının kontrol altına alınmasının ve hasta gereksinimlerinin kısa sürede ve uygun şekilde karşılanmasının etkili olduğu düşünülebilir. Mide kanserli hastaların operasyon sonrası ağrısını gidermede belirli noktalara elle basınç uygu- lamanın postoperatif ağrıyı azalttığı ve konforu arttırdığı bildirilmiştir (25). Meme kanseri nedeniyle radyoterapi gören hastalara görüntülü rehber kullanılmasının konforu arttırdığ 1 belirtilmiştir (26).

Üstündağ çalışmasında, bu çalışmanın tersine operasyon deneyiminin olmasının hastaların durumluk anksiyetelerini olumsuz etkilediğini bildirmiştir (2). Odasından memnun olmanın hastanın süreklilik anksiyetesini arttırmada etkili bir faktör olması beklenen bir sonuç değildir. $\mathrm{Bu}$ sonuç çalışma grubunu oluşturan hastaların oda koşullarını beğendikleri ancak anksiyetesini azaltmada etkili olacak kadar önemsemedikleri şeklinde yorumlanabilir. Çalışmamızın aksine Nuraini ve ark 2017 çalışmalarında oda koşullarının kötü olmasının konforu olumsuz etkilediğini bildirmişlerdir (15).

Çalışmada genel konfor düzeyi ile erken postoperatif konfor düzeyi arasında pozitif yönde ilişkili bulundu. Erken postoperatif dönemde konfor düzeyi artarken, genel konfor düzeylerinin de artması beklenen bir sonuçtur. Erken dönemi konforlu geçiren hastalar genel olarak rahatlamış hissedebilirler (27).

\section{Sonuç}

Elde edilen verilere göre göğüs cerrahisi uygulamasının konforu düşürmediği, ancak konfor ile özellikle durumluluk anksiyetesi arasında negatif yönde bir ilişkili olduğu ve daha önce hastane deneyimi olması, cerrahi girişim süresi, geçirilmiş ameliyat deneyiminin olması, yattığ 1 odadan memnun olma durumunun konfor veya ansiyeteyi etkileyen faktörler olduğu bulunmuştur. $\mathrm{Bu}$ sonuçlar doğrultusunda cerrahi operasyon geçiren hastaların özellikle anlık anksiyetelerini kontrol etmek ve hastanın önceki cerrahi deneyiminin göz önünde bulundurularak hemşirelik bakımlarının planlanması önerilebilir. Ayrıca farklı hasta gruplarında anksiyeteyi önleyici hemşirelik girişimleri uygulanarak bu önlemlerin hastanın konforuna etkisi değerlendirilebilir.

\section{Kaynaklar}

1. Karanci AN, Dirik G. Predictors of pre- and postoperative anxiety in emergency surgery patients. J Psychosom Res. 2003; 55:363-369.

2. Üstünda $\breve{g} H$. Koroner arter bypass greft cerrahisi uygulanan hastaların konfor düzeyi. [The Comfort Level of Patients Who 
Underwent Coronary Artery Bypass Graft Surgery]. Marmara Üniversitesi Sağl1k Bilimleri Enstitüsü, Doktora Tezi, 2009.

3. Büyükyılmaz FE, Şendir M, Acaroğlu R. Evaluation of night-time pain characteristics and quality of sleep in postoperative Turkish orthopedic patients. Clinical Nursing Research. 2011;20(3):326-42.

4. Atar NY, Kirbiyik E, Kaya N, Kaya H, Turan $\mathrm{N}$, Palloş A, et al. Bir üniversite hastanesinin cerrahi kliniğinde yatan hastaların uyku kalitesi ve uyku durumunu etkileyen faktörler [Patients' sleep quality and factors affecting sleep in surgery clinic of one university hospital]. Turkiye Klinikleri Journal of Nursing. [Turkiye Klinikleri Journal of Nursing]. 2012;4(2):74-84.

5. Cappuccio FP, Cooper D, D'elia L, Strazzullo $\mathrm{P}$, Miller MA. Sleep duration predicts cardiovascular outcomes: a systematic review and meta-analysis of prospective studies. European Heart Journal. 2011;32(12):1484-92.

6. Okanlı A, Özer N, Çevik Akyıl R, Koçkar Ç. Cerrahi kliniklerinde yatan hastaların anksiyete ve depresyon düzeylerinin belirlenmesi [Determining the anxiety and depression levels of the patients hospitalized in surgical clinics]. AÜ Hemşirelik Yüksekokulu Dergisi, 2006;9(4):38-44.

7. Yeğin A, Erdoğan A, Hadimioğlu N. Toraks cerrahisinde ameliyat sonrası analjezi. [Postoperative analgesia for thoracic surgery]. GKD Anest Yoğ Bak Dern Derg. [Turkish Thorac Cardiovasc Surg]. 2005;13(4):418-25.

8. Naithani U, Bajaj P, Bhatnagar N, Prasad C. One year prospective analysis of morbidity and mortality associated with thoracic surgery. Anaesth Pain \& Intensive Care. 2011;15(2):8692.

9. Iyer A, Yadav S. Postoperative care and complications after thoracic surgery. Principles and practice of cardiothoracic surgery: InTech; 2013. Erişim tarihi 10.03.2018

https://www.intechopen.com/books/citations/p rinciples-and-practice-of-cardiothoracicsurgery/postoperative-care-andcomplications-after-thoracic-surgery.

10. Yazkan R. Göğüs Cerrahisinde Postoperatif Komplikasyonlar. Journal of Clinical and
Analytical Medicine Kitap Serisi, Toraks Travmalar1 ve Tedavisi. 2010; 1:4;114-127.

11. Kolcaba K. Comfort Theory and Practice A vision for holistik health care and research, Springer Publishing Company, New York, 2003.

12. Pinto S, Caldeira S, Martins JC. Evolutionary analysis of the concept of comfort. Holist Nurs Pract 2017;31(4):243-252.

13. Cohen M, Torres-Vigil I, Burbach BE, Rosa A, Bruera $\mathrm{E}$. The meaning of parenteral hydration to family caregivers and pa-tients with advanced cancer receiving hospice care. J Pain Symptom Manage. 2012; 43:855-865.

14. Seyedfatemi N, Rafii F, Rezaei M, Kolkoba K. Comfort and hope in the preanesthesia stage in patients undergoing surgery. Journal of PeriAnesthesia Nursing, 2014; 29 (3): 213220.

15. Nuraini T, Gayatri D, Rachmawati İ. Comfort assessment of cancer patient in palliative care: A nursing perspective. International Journal of Caring Sciences. 2017;1(10):209-215.

16. Breitbart, W. Thoughts on the goals of psychosocial palliative care, Palliative Supportive Care. 2008; 6(3), 211-212.

17. Üstünda ğ H, Eti Aslan F. Perianestezi konfor ölçeğinin Türkçeye uyarlaması [The Turkish adaptation of perianesthesia confort questionnaire]. Turkiye Klinikleri J Nurs Sci. 2010;2(2):94-9.

18. Kolcaba K. Holistik Comfort: Operationalizing the construct as a nurse sensitive outcome, Advances in Nursing Science. 1992;15(1):110.

19. Kuğuoğlu S, Karabacak Ü. Genel konfor ölçeğinin Türkçeye uyarlanması [Turkish version of general confort questionaire]. İ.Ü. F. N. Hem. Derg. 2008; 16:61, 16-23.

20. Spielberger, Charles D. Anxiety as an Emotional State, Current Trend in Theory and Research içinde, Spielberger, Charles D. (derl.), Vol. 1, New York: Academic Press, 1972, s.24-49.

21. Öner N, Le Compte A. Durumluk Sürekli Kayg1 Envanteri El Kitab1 2. Bask1 İstanbul, Boğaziçi Üniversitesi yayınları, no:333,1985.

22. Gallo LC, Malek MJ, Gilbertson AD, Moore JL. J Behav Med. Perceived cognitive function and emotional distress following coronary 
artery bypass surgery. J Behav Med. 2005 Oct;28(5):433-42. Epub 2005 Sep 23.

23. Halcomb E, Salamonson, Cook A. Satisfaction and comfort with nursing in Australian general practice. Collegian. 2015;22: 199-205.

24. Apóstolo JLA and Kolcaba K. The effects of guided imagery on comfort, depression, anxiety, and stress of psychiatric inpatients with depressive disorders. Archives of Psychiatric Nursing.2009;23(6): 403-411.

25. Hsiung WT, Chang YC, Yeh ML, Chang YH. Acupressure improves the ostoperative comfort of gastric cancer patients: a randomised controlled trial. Complement Ther Med. 2015;23(3):339-346.

26. Kolcaba K, Fox C. The effects of guided imagery on comfort of women with early stage breast cancer undergoing radiation therapy. Oncol Nurs Forum. 1999;26(1):67-72.

27. Kim K, Kwon S \& Pcm B. C. Comfort and quality of life of cancer. Asian Nursing Research 2007; 1(2): 125-135. 